\title{
The Ability of a Tetrel Bond to Transition a Neutral Amino Acid into a Zwitterion
}

\author{
Mingchang Hou, ${ }^{\text {a }}$ Qingzhong Li, ${ }^{*, a}$ Steve Scheiner, ${ }^{*}$ \\ ${ }^{a}$ The Laboratory of Theoretical and Computational Chemistry, School of Chemistry and \\ Chemical Engineering, Yantai University, Yantai 264005, People's Republic of China. \\ ${ }^{b}$ Department of Chemistry and Biochemistry, Utah State University, Logan, UT 84322-0300, \\ USA
}

Corresponding authors:

Qingzhong Li, E-mail: lqz@ytu.edu.cn

Steve Scheiner, E-mail: steve.scheiner@usu.edu

\begin{abstract}
The interaction between glycine and $\mathrm{F}_{2} \mathrm{CO} / \mathrm{F}_{2} \mathrm{SiO}$ occurs through the formation of a $\pi$-tetrel bond between the $\mathrm{C} / \mathrm{Si}$ atom and a carboxyl $\mathrm{O}$ atom. The interaction energy is some $20 \mathrm{~kJ} / \mathrm{mol}$ for the $\mathrm{C} \cdots \mathrm{O}$ tetrel bond, but exceeds $300 \mathrm{~kJ} / \mathrm{mol}$ for $\mathrm{Si} \cdots \mathrm{O}$. As part of the latter complexation process, the proton engaged in the intramolecular $\mathrm{OH}^{*}{ }^{*} \mathrm{~N} \mathrm{H}$-bond is transferred across to the $\mathrm{N}$, forming a zwitterion. This $\mathrm{Si} \cdots \mathrm{O}$ tetrel bond is more effective at inducing this proton transfer than is placement of the glycine in an aqueous medium, complexation with an anionic $\mathrm{BH}_{4}^{-}$, or adding an electron to the glycine.
\end{abstract}

Keywords: glycine, $\mathrm{F}_{2} \mathrm{CO}, \mathrm{F}_{2} \mathrm{SiO}$; proton transfer 


\section{Introduction}

Noncovalent interactions have attracted increasing attention because of their extensive applications in crystal engineering [1,2], supramolecular chemistry [3-5] and chemical reactions [6,7]. Their influence in biological systems [8] is profound and our understanding of their behavior is necessary for elucidation of biological mechanisms. For example, hydrogen bonding plays an important role in maintaining the three-dimensional structures of biomolecules including peptides [9], proteins [10], carbohydrates, and nucleic acids [11]. A recent study showed that $\mathrm{H}$-bonding is of great importance in controlling the degradation of radical cations of DNA bases [12]. It is well known that intramolecular proton transfer is one of the simplest and most important reactions in biochemistry and is a key process in many biological systems [1315]. There are many possible protonation sites in biomolecules, and protons can be transferred from one site to another, which is a basic phenomenon in biological reactions [16].

Amino acids are the building blocks of proteins [17,18], and elucidating their configuration is correspondingly important. As the simplest amino acid glycine is often taken as a model, with extensive applications in food, medicine, enzyme catalysis, feed, and the chemical industry [19]. Polyglycine is mainly present in silk fibroin in the form of a $\beta$-sheet [19] and is a basic precursor for the synthesis of proteins, nucleic acids and lipids. The crystal structure of glycine was probed [20] as early as 1939, and its morphology elaborated [21]. Different forms of amphoteric glycine ions have different properties [22], resulting in a wide variety of functions [23]. Glycine and its protonated species have been thoroughly investigated by experimental and theoretical methods [23-30]. Although amino acids exist in their neutral forms in the gas phase, zwitterions predominate in aqueous solution. There are many factors that influence structural changes of glycine. For example, $\mathrm{H}$-bonding between the $\mathrm{BH}_{4}{ }^{-}$anion and glycine has a strong effect on glycine's configuration [31]; solvation [32,33] and ionization [34] also affect its structure.

The tetrel bond is a noncovalent bond involving atoms of group IV [35], with similarity to Hbonding, and numerous studies have accordingly focused on the structures, properties, strength, nature and applications of tetrel bonds [36-44]. In a recent study, our own group explored the effect of tetrel bonding on the strength of an intramolecular hydrogen bond in malondialdehyde (MDA) [45]. The $\pi$-tetrel bond strengthens/weakens the MDA internal H-bond when the bond is formed to the hydroxyl/carbonyl group of MDA, leading to inhibition/promotion of the proton transfer [45]. There is thus reason to inquire as to whether a similar sort of tetrel bond can affect, or even induce, intramolecular proton transfer in glycine?

This work thus reports the results of quantum calculations of the intramolecular $\mathrm{OH} \cdots \mathrm{N} \mathrm{H}-$ bond within glycine. A transfer of the bridging proton will transform the neutral glycine into a zwitterion. The $\mathrm{F}_{2} \mathrm{TO}$ molecule, with $\mathrm{T}=\mathrm{C}$ and $\mathrm{Si}$, has been shown earlier $[38,39,45]$ to be a potent tetrel bonding species via the $\pi$-hole that lies above its molecular plane. $\mathrm{F}_{2} \mathrm{CO}$ and $\mathrm{F}_{2} \mathrm{SiO}$ were each allowed to interact with glycine, scrutinizing the heterodimer potential energy surface for all possible minimum energy structures. For each structure, the preferred position of the bridging proton on the internal $\mathrm{OH} \cdots \mathrm{N}$ H-bond was identified, along with the energy barrier which must be surpassed in order for the neutral form to transit to the zwitterion. These effects 
were then compared to those of the $\mathrm{BH}_{4}{ }^{-}$anion which had been shown previously to affect proton position. Solvation effects were also considered as highly polar solvents are known to favor zwitterion formation.

\section{Computational Methods}

The Gaussian 09 program [46] was used to perform the optimization and frequency calculations at the MP2/aug-cc-pVTZ level. The absence of any imaginary frequencies verifies the optimized structures are true minima. Interaction energies were calculated using the supermolecular approach, in which the geometries of monomers in the complexes were taken as a point of reference. This quantity was corrected for the basis set superposition error (BSSE) by the counterpoise method of Boys and Bernardi [47]. Solvent $\left(\mathrm{H}_{2} \mathrm{O}\right)$ calculations were carried out by means of the polarizable continuum model (PCM) [48].

The second-order perturbation energy between pairs of orbitals was obtained at the HF/augcc-pVTZ level by the natural bond orbital (NBO) method [49]. Molecular electrostatic potentials (MEPs) on the 0.001 au contour of electron density were calculated at the MP2/aug-cc-pVTZ level using the wave function analysis-surface analysis suite (WFA-SAS) program [50]. Topological analyses were performed using the atoms in molecules (AIM) methodology [51]. AIM 2000 software [52] was used to calculate topological parameters including the electron density, its Laplacian and energy density at bond critical points (BCPs). Intrinsic reaction coordinate (IRC) calculation connected each transition state (TS) to the corresponding reactants and products.

\section{Results and Discussion}

The four different configurations of glycine monomer are illustrated in Figure 1, along with their relative energies. $\mathrm{G}^{\prime \prime}$ ' is the most stable geometry, wherein the $\mathrm{OH}$ of the $\mathrm{COOH}$ group is cis to the carbonyl $\mathrm{O}$ and the $\mathrm{NH}_{2}$ protons lie above and below the $\mathrm{N}-\mathrm{C}-\mathrm{C}-\mathrm{O}$ molecular plane. $\mathrm{G}$ lies $1.35 \mathrm{~kJ} / \mathrm{mol}$ higher in energy, differing from $\mathrm{G}^{\prime \prime}$ ' in that the $\mathrm{OH}$ is trans to the carbonyl $\mathrm{O}$. $3.42 \mathrm{~kJ} / \mathrm{mol}$ higher is the $\mathrm{G}$ ' ' structure where the $\mathrm{OH}$ is again cis to $\mathrm{C}=\mathrm{O}$ but the $\mathrm{NH}_{2}$ protons lie roughly in the molecular plane. $\mathrm{G}^{\prime}$ is least stable with its trans $\mathrm{OH}$ and position of the $\mathrm{NH}_{2}$ protons toward the $\mathrm{OH}$. Although known to be neutral in the gas phase, as in the four configurations in Fig 1, the $\mathrm{OH}$ proton transfers to the $\mathrm{NH}_{2}$ group in the aqueous phase, leading to the well known zwitterionic form. Since this proton transfer can only occur through a cis structure, and as $\mathrm{G}^{\prime}$ is $23 \mathrm{~kJ} / \mathrm{mol}$ less stable than $\mathrm{G}$, it is the latter configuration that is chosen as the focus of this study of proton transfer.

Previous calculations have shown a number of external influences can cause the proton transfer to a zwitterionic form. Inclusion of a number of water molecules, for example, preferentially stabilizes the zwitterion through the intermediacy of their H-bonds [53-55]. Another prior work had concluded that even a single intermolecular $\mathrm{H}$-bond to the $\mathrm{NH}_{2}$ group of $\mathrm{G}$ can promote this transfer [31]. Another work [45] demonstrated that a tetrel bond to $\mathrm{F}_{2} \mathrm{TO}$ $(\mathrm{T}=\mathrm{C}, \mathrm{Si}$ ) induces a proton transfer within malondialdehyde (MDA). The question then arises as to whether this same sort of tetrel bond might similarly cause a proton transfer in glycine. 
As a preliminary step in understanding any such tetrel bond, the molecular electrostatic potential (MEP) of $\mathrm{G}$, and both $\mathrm{F}_{2} \mathrm{CO}$ and $\mathrm{F}_{2} \mathrm{SiO}$ are pictured in Figure 2. Negative (blue) regions are found on both the hydroxyl and carbonyl $\mathrm{O}$ atoms, with the latter more negative. There are positive red areas ( $\pi$-holes) above and below the molecular plane of $\mathrm{F}_{2} \mathrm{TO}$; the values of the maximum indicated in Figure 2 make the $\pi$-hole above the Si atom twice as intense as those above the $\mathrm{C}$ atom. Based on these patterns, one can certainly envision a $\pi$-hole tetrel bond between either $\mathrm{O}$ atom of $\mathrm{G}$ and the $\pi$-hole of $\mathrm{F}_{2} \mathrm{TO}$. However, attempts to form a tetrel bond with the hydroxyl $\mathrm{O}$ failed; it is only the carbonyl $\mathrm{O}$ that engages in such a bond.

When the $\mathrm{F}_{2} \mathrm{TO} \pi$-hole approaches the carbonyl $\mathrm{O}$ atom, three structures are obtained, denoted as a, b, and c in Figure 3. The a structure contains a "pure" tetrel bond, i.e. no significant secondary interactions. The $\mathrm{b}$ dimer also contains a pair of $\mathrm{CH} \cdots \mathrm{F} \mathrm{H}$-bonds, while $\mathrm{c}$ supplements the primary tetrel bond with a pair of $\mathrm{CH} \cdots \mathrm{O}$-bonds. Whether $\mathrm{T}=\mathrm{C}$ or $\mathrm{Si}$, it is the $\mathrm{c}$ configuration that is most stable, followed by $\mathrm{b}$ and then by a. There is a big difference between $\mathrm{C}$ and $\mathrm{Si}$ energetics. The interaction energies for $\mathrm{T}=\mathrm{Si}$ vary from 175 to $320 \mathrm{~kJ} / \mathrm{mol}$ while the $\mathrm{C}$ values are all less than $25 \mathrm{~kJ} / \mathrm{mol}$. Along with the stronger Si tetrel bonds is a much shorter $\mathrm{R}(\mathrm{T} \cdots \mathrm{O})$ distance: $1.8 \AA$ for Si vs $2.6 \AA$ for $\mathrm{C}$.

The tetrel bond formation causes an elongation of the internal $\mathrm{O}-\mathrm{H}$ bond length in $\mathrm{G}$. Equaling to $0.984 \AA$ in the $\mathrm{G}$ monomer, it stretches slightly by $0.002-0.006 \AA$ for the $\mathrm{F}_{2} \mathrm{CO}$ complexes. But this stretch is magnified in the stronger Si tetrel bonded complexes. Indeed, $\mathrm{r}(\mathrm{OH})$ is considerably longer than $\mathrm{r}(\mathrm{NH})$ in both the $\mathrm{b}$ and c complexes of $\mathrm{F}_{2} \mathrm{SiO}$. The short $\mathrm{r}(\mathrm{NH})$ distances of less than $1.08 \AA$, with $\mathrm{r}(\mathrm{OH}) \sim 1.6 \AA$, can be characterized as a full-fledged proton transfer from $\mathrm{O}$ to $\mathrm{N}$.

The idea that a proton transfer has occurred is further bolstered by AIM topological parameters of the electron density. The quantities associated with the $\mathrm{NH}$ and $\mathrm{OH}$ bond critical points are displayed in Table 1. The covalent $\mathrm{OH}$ bond in monomer $\mathrm{G}$ is clear by the large values of $\rho, \nabla^{2} \rho$, and $H$ in the corresponding columns of the first row of Table 1, dwarfing the $\mathrm{NH}$ values preceding them. The density Laplacian is negative for $\mathrm{OH}$, and positive for $\mathrm{NH}$, consistent with their respective covalent and noncovalent character [56]. This pattern continues for all of the complexes, with the exception of $\mathrm{G}-\mathrm{F}_{2} \mathrm{SiO}-\mathrm{b}$ and $\mathrm{G}-\mathrm{F}_{2} \mathrm{SiO}-\mathrm{c}$ in the last two rows. It is here that the order reverses and the AIM quantities are much larger for $\mathrm{NH}$ than for $\mathrm{OH}$, and the $\mathrm{OH}$ Laplacian becomes positive, while that for $\mathrm{NH}$ turns negative.

From a more subtle perspective, the formation of the tetrel-bonded complexes can be seen to strengthen the internal $\mathrm{OH} \cdots \mathrm{N}$ H-bond, even when no transfer occurs. Skimming down the columns of Table 1 shows small increases in the N-H parameters, coupled with small decreases in the corresponding $\mathrm{O}-\mathrm{H}$ quantities. This same pattern is observed for the NBO interorbital charge transfers in the last column of Table 1 . These entries refer to the $L p(N) \rightarrow \sigma^{*}(\mathrm{O}-\mathrm{H})$ for the $\mathrm{OH} \cdots \mathrm{N} \mathrm{H}$-bonded cases, and $\mathrm{Lp}(\mathrm{O}) \rightarrow \sigma^{*}(\mathrm{~N}-\mathrm{H})$ for the last two rows after the proton has transferred to the $\mathrm{N}$. Note that there is a strong $\mathrm{NH} \cdots \mathrm{O} \mathrm{H}$-bond after the transfer has occurred.

While the interaction energies shown in Figure 3 are quite large, it should be stressed that this quantity refers to the interaction between monomers that have already been distorted into the 
geometries they adopt within the complex. As such, there is a certain amount of monomer deformation energy that must be overcome before this encounter can occur. These deformation energies are listed in the last column of Table 2, where it may be seen that they are quite large for the $\mathrm{F}_{2} \mathrm{SiO}$ complexes, as much as $155 \mathrm{~kJ} / \mathrm{mol}$. Much of this distortion is associated with loss of planarity in the $\mathrm{F}_{2} \mathrm{SiO}$ monomer, transitioning toward the pyramidal structure necessary to engage in the very strong tetrel bond. When these deformation energies are subtracted from $\mathrm{E}_{\text {int }}$, one has the binding energies $E_{b}$, that take the system from a pair of isolated monomers in their optimum geometries, to the complexes indicated. $\mathrm{E}_{\mathrm{b}}$ is less than $24 \mathrm{~kJ} / \mathrm{mol}$ for the $\mathrm{F}_{2} \mathrm{CO}$ complexes but in the $128-167 \mathrm{~kJ} / \mathrm{mol}$ range for $\mathrm{F}_{2} \mathrm{SiO}$.

Whereas the global minimum may place the proton on either the $\mathrm{N}$ or the $\mathrm{O}$, there may be a secondary minimum on the potential energy surface corresponding to its placement on the other atom. In the case of glycine itself, there is no such second minimum, as the $\mathrm{OH} \cdots \mathrm{N}$ structure represents the only minimum. The same is true if $\mathrm{G}$ engages in a complex with $\mathrm{F}_{2} \mathrm{CO}$. Upon complexation with $\mathrm{F}_{2} \mathrm{SiO}$, the result depends upon the specific structure. Within the context of the a and b structures, the $\mathrm{OH}^{\cdot} \cdot \mathrm{N}$ geometry is considerably more stable than $\mathrm{O} \cdot{ }^{*} \mathrm{HN}$, by 16.5 and $6.2 \mathrm{~kJ} / \mathrm{mol}$, respectively. Indeed, the well containing the secondary minimum is so shallow that it is difficult to isolate the transition state separating them, so a spontaneous decay to $\mathrm{OH} \cdot \mathrm{N}$ is anticipated. In the c geometry, on the other hand, the two minima are very similar in energy, with $\mathrm{NH}^{*} \mathrm{O}$ the more stable, but by only $0.3 \mathrm{kcal} / \mathrm{mol}$. The proton transfer would be nearly spontaneous since a barrier of only $8.4 \mathrm{~kJ} / \mathrm{mol}$ must be surmounted.

It is well known that a polar environment such as an aqueous medium favors a zwitterionic form of an amino acid such as glycine. And indeed, this influence was clear when $\mathrm{G}$ was placed in a PCM dielectric continuum model of water, where the solvation causes the appearance of a second minimum in the proton-transfer potential, corresponding to the zwitterionic form. The zwitterion is $5.8 \mathrm{~kJ} / \mathrm{mol}$ higher in energy than the neutral $\mathrm{OH} \cdots \mathrm{N}$ configuration, separated from it by a barrier of $17.1 \mathrm{~kJ} / \mathrm{mol}$. But what is striking is that even solvation by water exerts less of a force to push the proton from $\mathrm{O}$ to $\mathrm{N}$, than does a single tetrel-bonding $\mathrm{F}_{2} \mathrm{SiO}$ which makes the zwitterion the preferred structure, and reduces the transfer barrier.

In a similar vein, a prior theoretical study [31] on the intramolecular proton transfer in glycine considered the influence of $\mathrm{B} \mathrm{BH}_{4}{ }^{-}$anion which engages in a dihydrogen bond with the $\mathrm{NH}$ proton in the glycine molecule. By enhancing the ability of the $\mathrm{N}$ atom to accept a proton, this anion facilitated the transfer of the $-\mathrm{COOH}$ proton to the $\mathrm{N}$ atom. The question thus arises as to whether such a dihydrogen bond exerts a stronger influence on the proton transfer than does the tetrel bond discussed above. In the $\mathrm{BH}_{4}{ }^{-}$case, the $\mathrm{NH} \cdots \mathrm{O}$ configuration was calculated to be less stable than $\mathrm{OH} \cdots \mathrm{N}$ by $3.1 \mathrm{~kJ} / \mathrm{mol}$, as opposed to the tetrel-bonded $\mathrm{G}-\mathrm{F}_{2} \mathrm{SiO}-\mathrm{c}$ where it is the former proton-transferred structure that is more stable. Moreover, the transition state is much higher for $\mathrm{BH}_{4}^{-}, 13.8 \mathrm{~kJ} / \mathrm{mol}$. The greater ability of the neutral tetrel-bonding $\mathrm{F}_{2} \mathrm{SiO}$ to facilitate the proton transfer, when compared to a full-fledged anionic $\mathrm{BH}_{4}{ }^{-}$is a further testament to the power of this sort of interaction to induce structural changes. 
It is interesting to consider how the process might be affected by the addition of an excess electron. Optimization of the glycine anion found that the $\mathrm{OH} \cdots \mathrm{N}$ configuration is more stable than $\mathrm{NH} \cdots \mathrm{O}$ by $22 \mathrm{~kJ} / \mathrm{mol}$. IRC identification of the transition state to proton transfer in this anion indicates an energy barrier of $24.1 \mathrm{~kJ} / \mathrm{mol}$. Thus while the anion does appear to have two separate minima, the energy barrier is higher than that associated with the tetrel bond or placing the system within the confines of aqueous solution.

\section{Conclusions}

In summary, both $\mathrm{F}_{2} \mathrm{CO}$ and $\mathrm{F}_{2} \mathrm{SiO}$ can engage in a complex with glycine, the latter being much stronger than the former. The complexes are held together primarily by a $\pi$-tetrel bond wherein the glycine $\mathrm{O}$ atom lies above the $\mathrm{F}_{2} \mathrm{TO}$ molecular plane. The $\mathrm{Si} \cdots \mathrm{O}$ tetrel bond is especially strong, approaching the characteristics of a covalent bond. In one of the three interaction modes with $\mathrm{F}_{2} \mathrm{SiO}$, the $-\mathrm{COOH}$ proton can be transferred to the $-\mathrm{NH}_{2}$ group, forming a zwitterion of energy no higher than the normal $\mathrm{OH} \cdots \mathrm{N}$ form. The two wells in the proton transfer potential are separated by an energy barrier of $8 \mathrm{~kJ} / \mathrm{mol}$. This tetrel bond with $\mathrm{F}_{2} \mathrm{SiO}$ is more effective at promoting the proton transfer from $\mathrm{O}$ to $\mathrm{N}$ than is i) placement within the context of aqueous medium, ii) complexation with a $\mathrm{BH}_{4}^{-}$anion, or iii) adding an extra electron to the glycine unit.

\section{Acknowledgements}

This work was supported by the National Natural Science Foundation of China (21573188).

\section{References}

1. P.G. Taylor, A.R. Bassindale, Y.E. Aziz, M. Pourny, R. Stevenson, M.B. Hursthouse, S.J. Coles. Dalton. Trans. 41 (2012) 2048.

2. A.R. Bassindale, M. Pourny, P.G. Taylor, M.B. Hursthouse, M.E. Light. Angew. Chem. Int. Ed. 115 (2010) 3612.

3. G. Mahmoudi, A. Bauzá, A. Frontera. Dalton. Trans. 45 (2016) 4965.

4. G. Mahmoudi, A. Bauzá, M. Amini, E. Molins, J.T. Mague, A. Frontera. Dalton. Trans. 45 (2016) 10708.

5. M.S Gargari, V. Stilinović, A. Bauzá, A. Frontera, P. McArdle, D.V. Derveer, S.W. Ng, G. Mahmoudi. Chem-Eur. J. 21 (2015) 17951.

6. J. Mikosch, S. Trippel, C. Eichhorn, R. Otto, U. Lourderaj, J.X. Zhang, W.L. Hase, M. Weidemüller, R. Wester. Science 319 (2008) 183.

7. S.J. Grabowski, Phys. Chem. Chem. Phys. 16 (2014) 1824.

8. X. García-LLinás, A. Bauzá, S.K. Seth, A. Frontera, J. Phys. Chem. A 121 (2017) 5371.

9. H. Park, J. Yoon, C. Seok. J. Phys. Chem. B. 112 ( 2008) 1041.

10. M. Jelokhani-Niaraki, L.H. Kondejewski, L.C. Wheaton, R.S. Hodges, J. Med. Chem. 52 (2009) 2090.

11. V. Gosein, T.F. Leung, O. Krajden, G.J. Miller, Protein Sci. 21 (2012) 737.

12. Y.H. Wang, H.M. Zhao, C.F. Yang, J.L. Jie, X.J. Dai, Q. Zhou, K.H. Liu, D. Song, H.M. Su. J. Am. Chem. Soc. 141 (2019) 1970.

13. P.F. Barbara, Chem. Phys. 136 (1989) 153.

14. V.A. Benderskii, V.I. Goldanskii, J. Jortner, Chem. Phys. 170 (1993) 265.

15. G.J. Kearley, F. Fillaux, M.H. Baron, S. Bennington, J. Tomkinson, Science 264 (1994) 
1285.

16. K. Zhang, A. Chung-Phillips, J. Chem. Inf. Model. 39 (1999) 382.

17. V. Barone, C. Adamo, F. Lelj, J. Chem. Phys. 102 (1995) 364.

18. A.G. Csaszar. J. Am. Chem. Soc. 114 (1992) 9568.

19. A.A. Larson, Pharmacol. Biochem. Be. 32 (1989) 505.

20. G. Albrecht, R.B. Corey, J. Am. Chem. Soc. 61 (1939) 1087.

21. P.D. Godfrey, R.D. Brown, F.M. Rodgers, J. Mol. Struct. 376 (1996) 65.

22. R.D. Brown, P.D. Godfrey, J.W.V. Storey, M.P. Bassez, Chem. Comm. 13 (1978) 547.

23. P.D. Godfrey, R.D. Brown, J. Am. Chem. Soc. 117 (1995) 2019.

24. K. Chung, R.M. Hedges, R.D. Macfarlane, J. Am. Chem. Soc. 98 (1976) 7523.

25. L.R. Wright, R.F. Borkman, A.M. Gabriel, J. Phys. Chem. 86 (1982) 3951.

26. J.H. Jensen, M.S. Gordon, J. Am. Chem. Soc. 113 (1991) 7917.

27. S. Bouchonnet, Y. Hoppilliard, Org. Mass Spectrom. 27 (1992) 71.

28. F. Jensen, J. Am. Chem. Soc. 114 (1992) 9533.

29. A.G. Császár, J. Am. Chem. Soc. 114 (1992) 9568.

30. R.F. Frey, J. Coffin, S.Q. Newton, M. Ramek, V.K.W. Chang, F.A. Momany, L. Schäfer, J. Am. Chem. Soc. 114 (1992) 5369.

31. S.X. Tian, H.B. Li, J.L. Yang, ChemPhysChem 10 (2009) 1435.

32. I. Tuñón, E. Silla, J. Phys. Chem. A 102 (1998) 8673.

33. B. Balta, V. Aviyente, J. Comput. Chem. 24 (2003) 1789.

34. M. Gutowski, P. Skurski, J. Simons, J. Am. Chem. Soc. 122 (2000) 10159.

35. A. Bauzá, T.J. Mooibroek, A. Frontera, Angew. Chem. Int. Ed. 52 (2013) 12317.

36. Q.Z. Li, H.Y. Zhuo, H.B. Li, Z.B. Liu, W.Z. Li, J.B. Cheng, J. Phys. Chem. A 119 (2015) 2217.

37. Q.Z. Li, X. Guo, X. Yang, W.Z. Li, J.B. Cheng, H.B. Li, Phys. Chem. Chem. Phys. 16 (2014) 11617.

38. X. Guo, Y.W. Liu, Q.Z. Li, W.Z. Li, J.B. Cheng, Chem. Phys. Lett. 620 (2015) 7.

39. H.L. Xu, J.B. Cheng, X. Yang, Z.B Liu, B. Xiao, W.Z. Li, Q.Z. Li, ChemPhysChem 18 (2017) 2442.

40. M.X. Liu, Q.Z. Li, J.B. Cheng, W.Z. Li, H.B Li, J. Chem. Phys. 145 (2016) 224310.

41. M.X. Liu, Q.Z Li, S. Scheiner, Phys. Chem. Chem. Phys. 19 (2017) 5550.

42. S. Scheiner, Chem-Eur. J. 22 (2016) 18850.

43. S. Scheiner, J. Phys. Chem. A 121 (2017) 5561.

44. A. Karim, N. Schulz, H. Andersson, B. Nekoueishahraki, A.C.C. Carlsson, D. Sarabi, A. Valkonen, K. Rissanen, J. Gräfenstein, S. Keller, M. Erdélyi, J. Am. Chem. Soc. 140 (2018) 17571.

45. Y.X. Wei, Q.Z. Li, S. Scheiner, ChemPhysChem 19 (2018) 736.

46. M.J. Frisch, G.W. Trucks, H.B. Schlegel, et al., GAUSSIAN 09, revision A.02, Gauss-ian, Inc., Wallingford, CT, 2009.

47. S.F. Boys, F. Bernardi, Mol. Phys. 19 (1970) 553.

48. V. Barone. M. Cossi, J. Phys. Chem. A. 102 (1998) 1995.

49. A.E. Reed, L.A. Curtiss, F. Weinhold, Chem. Rev. 88 (1988) 899.

50. F.A. Bulat, A. Toro-Labbé, T. Brinck, J.S. Murray, P. Politzer, J. Mol. Model. 16 (2010) 1679.

51. R.F.W. Bader, Oxford University Press, Oxford, UK, 1990.

52. F. Biegler-König, AIM2000, University of Applied Sciences, Bielefeld, Germany, 2000. 
53. J.H. Jensen, M.S. Gordon, J. Am. Chem. Soc. 117 (1995) 8159.

54. R.P. de Tudela, D. Marx, J. Phys. Chem. Lett. 7 (2016) 5137.

55. Valverde, Z.M. da C. Ludwig, C.R. da Costa, V. Ludwig, H.C. Georg, J. Chem. Phys. 148 (2018) 024305.

56. W.D. Arnold, E. Oldfield, J. Am. Chem. Soc. 122(2000) 12835. 
Table 1 Electron density ( $\rho$, au), its Laplacian $\left(\nabla^{2} \rho\right.$, au) and energy density $(H$, au) at the N-H and $\mathrm{O}-\mathrm{H}$ BCPs as well as second-order NBO perturbation energy $\left(\mathrm{E}^{2}, \mathrm{~kJ} / \mathrm{mol}\right)$ in the $\mathrm{G}$ monomer and its complexes with $\mathrm{F}_{2} \mathrm{TO}$

\begin{tabular}{llllllll}
\hline & $\rho_{\mathrm{N}-\mathrm{H}}$ & $\nabla^{2} \rho_{\mathrm{N}-\mathrm{H}}$ & $H_{\mathrm{N}-\mathrm{H}}$ & $\rho_{\mathrm{H}-\mathrm{O}}$ & $\nabla^{2} \rho_{\mathrm{H}-\mathrm{O}}$ & $H_{\mathrm{H}-\mathrm{O}}$ & $\mathrm{E}^{2 \mathrm{a}}$ \\
\hline $\mathrm{G}$ & 0.036 & 0.115 & -0.002 & 0.347 & -2.705 & -0.737 & 53.55 \\
$\mathrm{G}-\mathrm{F}_{2} \mathrm{CO}-\mathrm{a}$ & 0.037 & 0.115 & -0.003 & 0.344 & -2.686 & -0.731 & 58.77 \\
$\mathrm{G}_{2} \mathrm{~F}_{2} \mathrm{CO}-\mathrm{b}$ & 0.037 & 0.113 & -0.003 & 0.340 & -2.642 & -0.719 & 72.61 \\
$\mathrm{G}_{-} \mathrm{F}_{2} \mathrm{CO}-\mathrm{c}$ & 0.038 & 0.116 & -0.003 & 0.343 & -2.681 & -0.730 & 62.49 \\
$\mathrm{G}_{-} \mathrm{F}_{2} \mathrm{SiO}-\mathrm{a}$ & 0.046 & 0.114 & -0.008 & 0.322 & -2.520 & -0.686 & 99.28 \\
$\mathrm{G}_{-} \mathrm{F}_{2} \mathrm{SiO}-\mathrm{b}$ & 0.291 & -1.919 & -0.519 & 0.065 & 0.153 & -0.018 & 161.81 \\
$\mathrm{G}-\mathrm{F}_{2} \mathrm{SiO}-\mathrm{c}$ & 0.301 & -2.012 & -0.542 & 0.059 & 0.158 & -0.014 & 133.17 \\
\hline
\end{tabular}

${ }^{\text {a }} \mathrm{E}^{2}$ corresponds to the orbital interaction of $\mathrm{Lp}(\mathrm{O}) \rightarrow \sigma^{*}(\mathrm{~N}-\mathrm{H})$ in $\mathrm{G}-\mathrm{F}_{2} \mathrm{SiO}-\mathrm{b}$ and $\mathrm{G}-\mathrm{F}_{2} \mathrm{SiO}-\mathrm{c}$ but $\mathrm{Lp}(\mathrm{N}) \rightarrow \sigma^{*}(\mathrm{O}-\mathrm{H})$ in other cases.

Table 2. Interaction energy ( $\left.E_{\mathrm{int}}\right)$, binding energy $\left(\mathrm{E}_{\mathrm{b}}\right)$ and deformation energy (DE), all in $\mathrm{kJ} / \mathrm{mol}$

\begin{tabular}{llll}
\hline & $\mathrm{E}_{\text {int }}$ & $\mathrm{E}_{\mathrm{b}}$ & $\mathrm{DE}$ \\
\hline $\mathrm{G}-\mathrm{F}_{2} \mathrm{CO}-\mathrm{a}$ & -18.70 & -17.93 & 0.77 \\
$\mathrm{G}-\mathrm{F}_{2} \mathrm{CO}-\mathrm{b}$ & -19.30 & -13.81 & 5.49 \\
$\mathrm{G}-\mathrm{F}_{2} \mathrm{CO}-\mathrm{c}$ & -24.78 & -23.60 & 1.18 \\
$\mathrm{G}-\mathrm{F}_{2} \mathrm{SiO}-\mathrm{a}$ & -175.42 & -127.74 & 47.68 \\
$\mathrm{G}-\mathrm{F}_{2} \mathrm{SiO}-\mathrm{b}$ & -283.58 & -128.90 & 154.67 \\
$\mathrm{G}-\mathrm{F}_{2} \mathrm{SiO}-\mathrm{c}$ & -320.10 & -166.75 & 153.36 \\
\hline
\end{tabular}




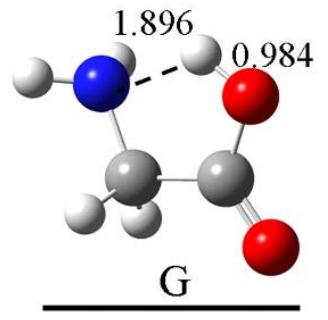

$0 \mathrm{~kJ} / \mathrm{mol}$
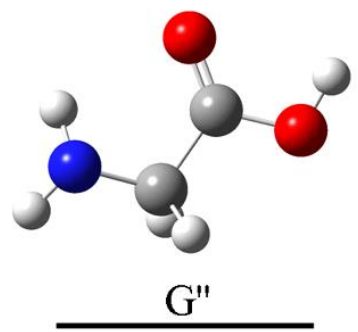

$3.42 \mathrm{~kJ} / \mathrm{mol}$

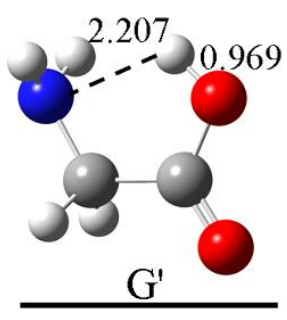

$22.76 \mathrm{~kJ} / \mathrm{mol}$

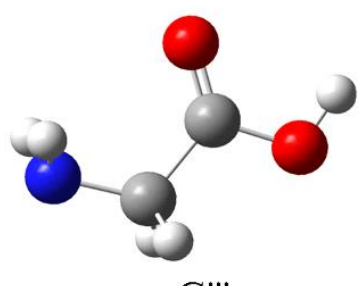

$-1.35 \mathrm{~kJ} / \mathrm{mol}$

Figure 1 The four configurations of glycine; distances in $\AA$

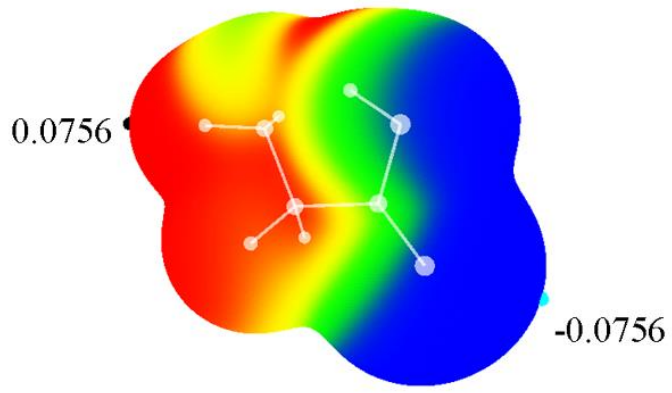

G

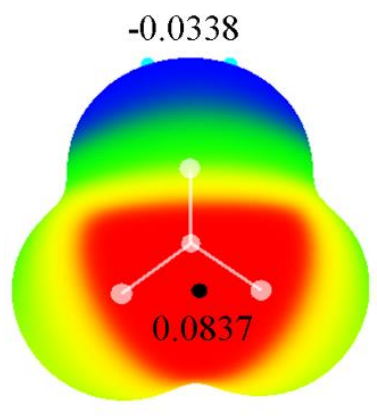

$\mathrm{F}_{2} \mathrm{CO}$
$-0.0688$

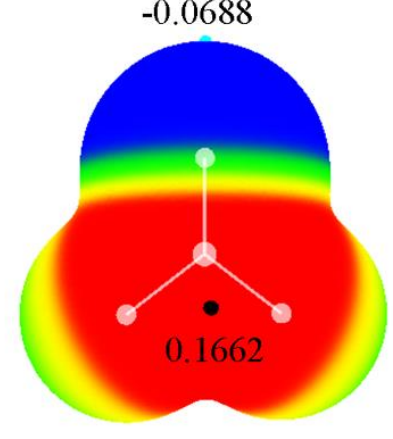

$\mathrm{F}_{2} \mathrm{SiO}$

Figure 2. MEP maps of monomers. Color ranges are: red, greater than 0.03; yellow, between 0.03 and 0 ; green, between 0 and -0.03 ; blue, less than -0.03 . Values of the MEP at maxima and minima on the surface are indicated in au. 


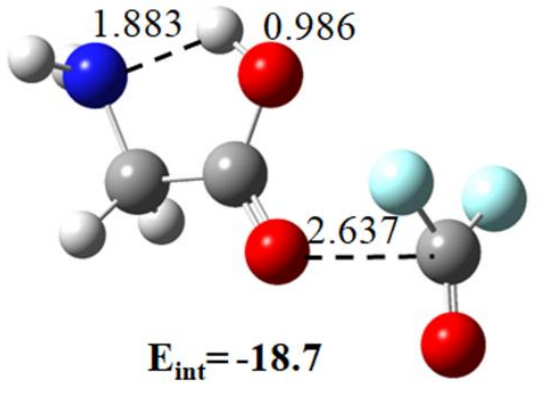

$\mathrm{G}-\mathrm{F}_{2} \mathrm{CO}-\mathrm{a}$

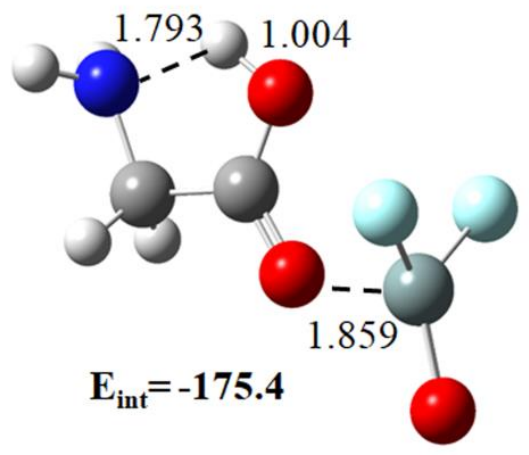

$\mathrm{G}-\mathrm{F}_{2} \mathrm{SiO}-\mathrm{a}$

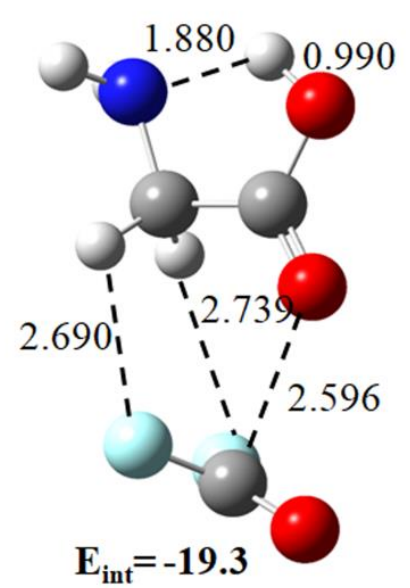

$\mathrm{G}-\mathrm{F}_{2} \mathrm{CO}-\mathrm{b}$

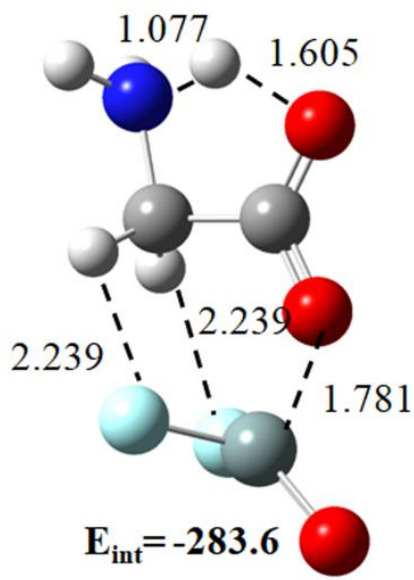

G-F $\mathrm{F}_{2} \mathrm{SiO}-\mathrm{b}$

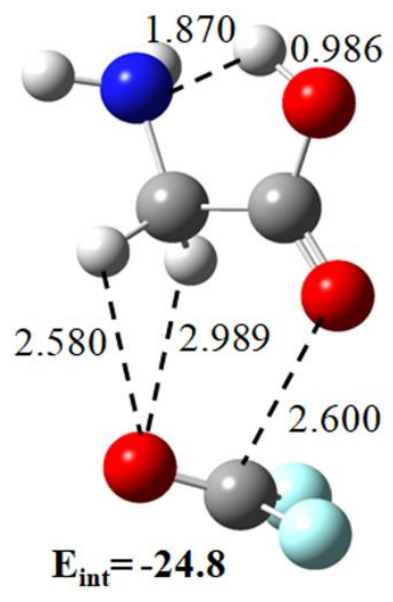

$$
\mathrm{G}-\mathrm{F}_{2} \mathrm{CO}-\mathrm{c}
$$

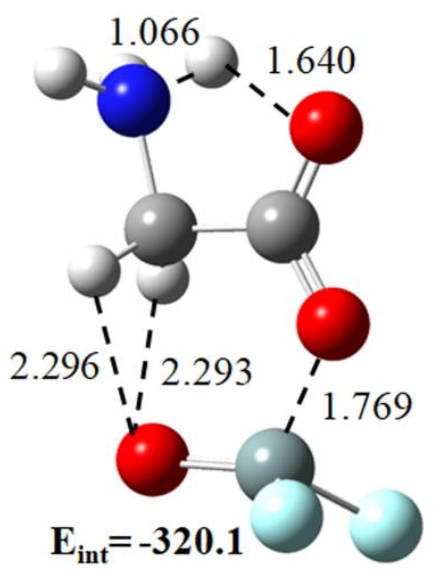

$\mathrm{G}-\mathrm{F}_{2} \mathrm{SiO}-\mathrm{c}$

Figure 3 Structures of three types of complexes between glycine and $\mathrm{F}_{2} \mathrm{TO}$. Interaction energies $\mathrm{E}_{\text {int }}$ in $\mathrm{kJ} / \mathrm{mol}$, and distances in $\AA$ 